\title{
PENGUATAN PENDIDIKAN KARAKTER KERJA KERAS PADA ANAK MELALUI PERMAINAN TRADISIONAL ENGKLEK DI DUSUN PULE, TEGALRANDU, SRUMBUNG, MAGELANG
}

\author{
Alfi Dwi Cahyani, Puji Lestari, dan Aris Martiana \\ Jurusan Pendidikan Sosiologi, Fakultas IImu Sosial, Universitas Negeri Yogyakarta \\ e-mail: alfi.dwi44@gmail.com
}

\begin{abstract}
Abstrak
Penelitian ini mendeskripsikan tahapan permainan tradisional Engklek dan implementasi pendidikan karakter kerja keras pada anak dalam kehidupan sehari-hari di Dusun Pule, Tegalrandu, Srumbung, Magelang. Penelitian ini menggunakan metode kualitatif deskriptif. Pengambilan sampel menggunakan teknik purposive sampling dengan jumlah informan 7 orang. Teknik pengumpulan data dilakukan dengan wawancara, observasi, dan dokumentasi. Validitas data yang digunakan adalah triangulasi sumber. Teknik analisis data menggunakan teknik analisis data milik Miles dan Huberman meliputi pengumpulan data, reduksi data, penyajian data, dan penarikan kesimpulan. Hasil penelitian ini menunjukkan bahwa tahapan permainan tradisional Engklek di Dusun Pule dibagi menjadi dua yaitu tahap pra permainan yang terdiri dari lima langkah dan tahap permainan yang juga terdiri dari lima langkah permainan. Adapun implementasi karakter kerja keras yang dilakukan oleh anak-anak dalam kehidupan sehari-hari, yaitu: (1) Tekun dan ulet (2) Teliti dan cermat (3) Menghargai waktu (4) Bekerja keras (5) Bekerja cerdas (6) Disiplin (7) Sabar (8) Ikhlas (9) Pantang menyerah.
\end{abstract}

Kata Kunci: Permainan Tradisional Engklek, Karakter Kerja Keras, Implementasi

\section{Abstract}

This study describes the stages of the traditional "Engklek" game and the implementation of character education of hard work in children in everyday life in Pule, Tegalrandu, Srumbung, Magelang. This research used descriptive qualitative method. Sampling used in this study is purposive sampling technique with 7 informants. Data collection techniques were obtained by interview, observation, and documentation. The validity of the data used in this study is source triangulation. Data analysis techniques used in this study were Miles and Huberman's data analysis techniques include data collection, data reduction, data presentation, and conclusion drawing. The results of this study indicate that the stages of the traditional "Engklek" game in Pule are divided into two stages, namely the pre game stage consisting of five steps and the game stage which also consists of five game steps. As for the implementation of hard work character done by children in everyday life, namely: (1) Diligent and resilient (2) Thorough and careful (3) Appreciate time (4) Work hard (5) Work smart (6) Discipline (7) Patience (8) Ikhlas (9) Never give up.

Keywords: Traditional "Engklek" Game, Hard Work Character, Implementation

\section{Pendahuluan}

Pendidikan dipersepsikan oleh Durkheim sebagai suatu kesatuan utuh dari masyarakat secara keseluruhan. Pendidikan sebagai dasar masyarakat menentukan proses alokasi dan distribusi sumber-sumber perubahan. Pendidikan juga dipandang sebagai institusi yang berfungsi sebagai "baby-sitting" yang bertugas agar warga masyarakat tidak ada yang memiliki perilaku menyimpang (Hanum, 2013:44). Di sisi lain, hasil pendidikan sangat berguna bagi usaha perbaikan sosial kemasyarakatan, menguatkan karakter bangsa, moral, dan memajukan kesejahteraan umat (Hanum, 2013:24). 
Namun yang menjadi permasalahan adalah, pendidikan yang didapatkan khususnya di sekolah ternyata belum mampu menanamkan dan mengatasi masalah-masalah moralitas dan karakter yang ada pada masyarakat terutama siswa atau anak. Hal ini dikarenakan kurikulum pendidikan masih mengedepankan aspek kognitif dan psikomotorik sebagai outcome learning, sedangkan aspek afektif yang notabene outcome pendidikan karakter hanya digunakan sebagai pelengkap dan persyaratan saja dalam menjalani proses pendidikan (Ansori, et al., 2016:3).

Untuk mengatasi hal tersebut, Presiden Joko Widodo dan Wakil Presiden Jusuf Kalla membentuk sebuah program untuk melakukan revolusi karakter bangsa yaitu gerakan PPK (Penguatan Pendidikan Karakter). Salah satu tujuan PPK yang termuat dalam Perpres Nomor 87 Tahun 2017 yaitu mengembangkan platform pendidikan nasional yang meletakkan pendidikan karakter sebagai jiwa utama dalam penyelenggaraan pendidikan bagi peserta didik dengan dukungan perlibatan publik yang dilakukan melalui pendidikan jalur formal, nonformal, dan informal dengan memperhatikan keberagaman budaya Indonesia. Merujuk pada salah satu tujuan dari PPK tersebut, penguatan pendidikan karakter bukan hanya didapatkan melalui pendidikan formal dan nonformal, tetapi juga pendidikan informal salah satunya yaitu pendidikan yang didapatkan dari lingkungan. Hasil penelitian di Baylor College of Medicine menyatakan bahwa lingkungan memberi peran yang sangat besar dalam pembentukan sikap, kepribadian, dan pengembangan kemampuan anak secara optimal (Malik, Kompasiana 7 April 2011).

Salah satu lingkungan yang dekat dengan anak adalah lingkungan bermain. Menurut Montessori (Yudiwinata \& Handoyo, 2014:3), lingkungan yang paling tepat bagi anak adalah bermain. Dalam dunia permainan, ada yang disebut dengan permainan tradisional dan ada yang digolongkan ke dalam permainan modern (Yulita, 2017:1). Menurut Sukirman (Mardayani dkk, 2016), permainan tradisional anak merupakan unsur kebudayaan, karena mampu memberi pengaruh terhadap perkembangan kejiwaan, sifat, dan kehidupan sosial anak di kemudian hari. Permainan tradisional mampu menanamkan nilai-nilai karakter pada anak. Kasnadi \& Sutejo (2017) menunjukkan bahwa di dalam permainan tradisional terkandung nilai-nilai pendidikan karakter. Nilai-nilai itu meliputi (1) karakter kerja sama, (2) karakter jujur, (3) karakter tanggung jawab, (4) karakter kerja keras, (5) karakter sportif, dan (6) karakter toleran. Dengan demikian, Penguatan Pendidikan Karakter (PPK) dapat dilakukan melalui pendidikan 
informal salah satunya melalui lingkungan yang masih mempertahankan permainan tradisional sebagai unsur dari kebudayaan disamping semakin pesatnya teknologi di era globalisasi ini.

Dusun Pule merupakan salah satu dusun dimana lingkungannya sampai saat ini masih mempertahankan budaya lokal salah satunya yaitu permainan tradisional. Salah satu permainan tradisional yang masih dimainkan oleh anak-anak Dusun Pule yaitu permainan tradisional Engklek. Montolalu (Apriani, 2013:2), mengatakan bahwa permainan tradisional Engklek merupakan permainan tradisional lompat-lompatan pada bidang-bidang datar yang digambar di atas tanah, dengan membuat gambar kotak-kotak kemudian melompat dengan satu kaki dari kotak satu ke kotak berikutnya. $\mathrm{Di}$ berbagai daerah, permainan tradisional Engklek memiliki nama-nama yang berbeda, salah satunya yaitu sondah mandah. Seperti yang dikatakan oleh Alif (2013:84), makna dan permainan tradisional yang ada di Indonesia memiliki pola-pola bermain yang sama seperti engkle, sondah mandah, sonlah, patikteuk, cak teu adalah satu permainan yang sama, sehingga permainan tradisional Engklek merupakan permainan yang memiliki kesamaan pola dan makna dengan permainan sondah mandah. Menurut Alif (2013:80), sondah mandah berasal dari kata zondag maandag (bahasa Belanda) yaitu nama-nama hari, yang menandai kotak tersebut Senin, Selasa sampai Minggu, dan diawali dari bumi atau earth sampai surga atau heaven. Makna yang diangkat dari permainan ini adalah bagaimana anak-anak sedang belajar menapaki kehidupan di tiap harinya dia harus berusaha keras dan tidak berlehaleha. Sampai dia mendapatkan tempat di bumi ini bahkan sampai mempunyai tempat di surga. Usaha keras itu ditandai dengan bentuk-bentuk gerakan yang dilakukan oleh pemain atau anak-anak dalam melewati kotak-kotaknya. Atas dasar tersebut, maka permainan sondah mandah atau Engklek memiliki makna permainan yang dapat menunjang karakter kerja keras pada anak.

Seperti Dusun Pule sendiri yang mana karakter kerja keras sudah menjadi karakter yang wajib dimiliki sedini mungkin sebagai bekal anak-anak untuk kehidupan selanjutnya. Mayoritas mata pencaharian warga Dusun Pule yang bekerja sebagai petani memberikan dampak pada penghasilan yang berada pada taraf menengah ke bawah, sehingga menjadikan karakter kerja keras begitu penting untuk dimiliki sejak dini. Di sisi lain, program pemerintah yaitu PPK menjadi dorongan untuk merealisasikan penanaman karakter melalui permainan tradisional. Untuk itu, permainan tradisional Engklek menjadi upaya yang dapat dilakukan untuk merealisasikan pendidikan karakter kerja keras pada 
anak sejak dini. Selain makna dari permainan tradisional Engklek yang mengajarkan anak untuk terus bekerja keras, permainan tradisional Engklek juga menjadi permainan yang sering dimainkan oleh anak-anak Dusun Pule. Melalui permainan tradisional Engklek, sang anak akan diajarkan tentang karakter kerja keras sejak dini. Sang anak dididik untuk terus melewati tahapan permainan dari awal hingga akhir. Semakin banyak tahapan yang dilewati, semakin sulit bentuk gerakan Engklek yang harus dilakukan oleh anak, sehingga membantu anak untuk belajar bekerja keras dan pantang menyerah. Oleh karena itu, peneliti melakukan penelitian mengenai "Penguatan Pendidikan Karakter Kerja Keras pada Anak melalui Permainan Tradisional Engklek di Dusun Pule, Tegalrandu, Srumbung, Magelang".

\section{Metode}

Penelitian ini menggunakan metode penelitian kualitatif dengan paparan deskriptif analisis. Teknik pengumpulan data menggunakan observasi, wawancara, dan dokumentasi. Pemilihan informan dalam penelitian ini menggunakan teknik purposive sampling dengan kriteria informan yaitu anak-anak Dusun Pule, sering bermain permainan tradisional Engklek, berusia 12 tahun agar diketahui jawaban yang lebih lengkap dan bervariatif. Sedangkan kriteria untuk informan ibu yaitu ibu yang memiliki anak berdasarkan purposive sampling dan memiliki pengalaman dalam bermain permainan tradisional Engklek. Adapun yang menjadi informan dalam penelitian ini adalah anak-anak, ibu dari masing-masing anak, serta Kepala Dusun Pule selaku penggerak program gerakan PPK.

\section{Hasil dan Pembahasan}

\section{Tahapan Permainan Tradisional}

Engklek di Dusun Pule, Tegalrandu, Srumbung, Magelang

Langkah-langkah yang ada dalam permainan tradisional Engklek di Dusun Pule dibagi menjadi dua tahap yaitu tahap pra permainan dan tahap permainan.

a. Langkah pertama dari tahap pra permainan

Menurut para informan, langkah pertama dari tahap pra permainan yaitu memanggil teman-teman yang akan bermain permainan tradisional Engklek. Istilah yang dipakai ketika anak-anak memanggil temannya yaitu ngampiri. Istilah tersebut merupakan istilah dalam permainan tradisional yaitu ketika satu atau beberapa anak memanggil teman lainnya di depan rumah seorang teman yang dipanggil. Ngampiri ini dilakukan di depan teras rumah dari seorang teman yang sedang dipanggil. Kemudian seorang anak yang dipanggil oleh temantemannya itu berarti anak tersebut 
diampiri.

b. Langkah kedua dari tahap pra permainan

Langkah kedua dari tahap pra permainan yaitu mencari tempat untuk bermain permainan tradisional Engklek. Berdasarkan hasil wawancara dan hasil observasi, tempat yang biasa digunakan oleh anak-anak untuk bermain yaitu di depan rumah seorang anak yang bernama Intan. Selain itu, tempat yang sering digunakan oleh anak-anak untuk bermain yaitu di lapangan yang terletak di depan majelis TPA. Tempat tersebut dipilih karena memiliki ukuran tanah yang luas sehingga nyaman untuk dijadikan tempat bermain anakanak. Tempat lainnya yang biasa dipilih oleh anak-anak untuk dijadikan tempat bermain yaitu di lapangan dusun. Lapangan dusun memiliki ukuran tanah yang lebih luas dibandingkan dengan lapangan yang terletak di depan majelis TPA.

c. Langkah ketiga dari tahap pra permainan

Setelah langkah pertama dan kedua selesai dilakukan, maka langkah selanjutnya atau langkah yang ketiga dari tahap pra permainan yaitu menggambar kotak-kotak permainan. Dalam menggambar kotak-kotak permainan, alangkah lebih baik jika kotak-kotak yang digambar tidak terlalu kecil namun juga tidak terlalu besar. Kotak yang digambar tidak terlalu kecil agar pemain dapat menginjakkan kaki dengan lebih leluasa. Selain itu, hal tersebut juga dilakukan agar dapat mengurangi kemungkinan garis permainan yang diinjak oleh kaki pemain. Kemudian kotak juga tidak terlalu besar agar pemain dapat menjangkau kotak satu ke kotak yang lainnya dengan mudah. Sebab jika kotak permainan terlalu besar, pemain akan kesulitan dalam melakukan engkling (melompat dengan satu kaki) dikarenakan kotak yang terlalu besar akan menghambat gerak kaki pemain dalam melompat. Berdasarkan hasil observasi, kotakkotak permainan tradisional Engklek yang digambar oleh anak-anak yaitu mempunyai bentuk yang hampir mirip dengan kincir angin. Di Dusun Pule sendiri, kincir angin biasa mereka sebut dengan kitiran.

d. Langkah keempat dari tahap pra permainan

Selanjutnya, langkah yang keempat yaitu para pemain mencari gacuk (benda yang digunakan dalam bermain Engklek) yang akan digunakan untuk bermain. Dalam langkah mencari gacuk, ada beberapa kriteria gacuk yang harus diperhatikan. Kriteria tersebut yaitu gacuk yang datar, agak lebar, dan tidak terlalu tebal serta tidak terlalu tipis. Berdasarkan hasil observasi, gacuk 
yang digunakan untuk bermain anakanak yaitu pecahan genting atau pecahan keramik mengingat kedua benda tersebut memiliki permukaan yang datar dan tidak terlalu bergelombang, serta memiliki ketebalan yang sedang. Gacuk yang digunakan oleh anak-anak dalam bermain permainan tradisional Engklek sama seperti jurnal penelitian oleh Apriani (2013:4) yang dalam penelitiannya mengungkapkan bahwa untuk dapat bermain setiap anak harus mempunyai kreweng atau gacuk yang biasanya berupa pecahan genting, keramik lantai atau pun batu yang datar.

e. Langkah kelima dari tahap pra permainan

Langkah yang terakhir dari tahap pra permainan yaitu para pemain secara bersama-sama melakukan hompimpa. Hompimpa menjadi salah satu cara yang digunakan oleh para pemain untuk melakukan undian pemain atau urutan pemain. Dalam pelaksanaannya, anak-anak berkumpul membentuk lingkaran kecil dan secara bersama-sama menyanyikan Lagu Hompimpa.

Setelah selesai menyanyikan lagu, para pemain dipersilahkan untuk menengadahkan tangan atau menelungkupkan tangannya. Pemain yang akan bermain terlebih dahulu adalah pemain yang memiliki posisi tangan yang paling berbeda.

Cara melakukan hompimpa tersebut sesuai dengan penelitian yang dilakukan oleh Cahyandari (2014:3) bahwa lagu hompimpa dinyanyikan bersama-sama oleh anakanak yang hendak bermain. Kemudian mereka melakukan gerakan menggoyang-goyangkan tangan. Ketika sampai pada bagian gambreng, masing-masing anak akan menaruh tangan mereka; ada yang menaruh telapak tangan dan ada yang menaruh punggung tangan. Biasanya, akan dicari satu anak yang berbeda.

f. Langkah pertama dari tahap permainan

Langkah pertama yang dilakukan oleh pemain dari tahap permainan ini adalah melempar gacuk pada salah satu kotak yang dipilih. Ketika gacuk sudah dilempar pada salah satu kotak, pemain langsung bisa melompat atau engkling (melompat dengan satu kaki) pada kotak-kotak permainan. Pada langkah pertama ini, pemain tidak dibebani dengan gacuk yang harus dibawa ketika sedang melakukan engkling, sehingga ini merupakan langkah yang paling mudah sebelum memasuki langkah-langkah selanjutnya.

g. Langkah kedua dari tahap permainan

Setelah langkah pertama dalam tahap permainan selesai, maka dilanjutkan dengan langkah kedua, 
yaitu pemain melakukan engkling dengan membawa gacuk di telapak tangan. Pada langkah ini, pemain membawa gacuk yang diletakkan di atas telapak tangan. Artinya, pemain harus membawa gacuk dengan posisi tangan yang menengadah tanpa menggenggam gacuk tersebut, sehingga dengan posisi tangan yang membawa gacuk di telapak tangan tanpa digenggam, pemain secara bersamaan juga harus melakukan engkling. Jika pemain tidak berkonsentrasi dan tidak hati-hati, maka pemain bisa saja menjatuhkan gacuk yang dibawanya. Sehingga pemain bukan hanya konsentrasi membawa gacuk saja, namun juga harus konsentrasi melakukan engkling.

h. Langkah ketiga dari tahap permainan Jika langkah kedua selesai, dilanjutkan pada langkah selanjutnya yaitu gacuk diletakkan di punggung tangan. Pada langkah ini, masih sama seperti langkah sebelumnya yaitu pemain melempar gacuk pada salah satu kotak. Jika gacuk yang dilempar jatuh tepat di dalam kotak maka pemain mengambil kembali gacuk yang telah dilempar sebelumnya. Hal tersebut dilakukan karena gacuk akan dibawa oleh pemain untuk diletakkan di punggung tangan. Dalam langkah ketiga ini, pemain melakukan engkling sembari membawa gacuk di punggung tangan.

i. Langkah keempat dari tahap permainan

Sama halnya dengan langkah ketiga, pemain masih melakukan engkling dengan membawa gacuk yang diletakkan di punggung tangan. Hanya saja punggung tangan yang membawa gacuk harus digoyangkan ke kanan dan ke kiri, tentunya hal tersebut dilakukan bersamaan saat pemain melakukan engkling. Memasuki langkah ketiga dan keempat memang menjadi langkah yang semakin sulit untuk dilakukan.

j. Langkah kelima dari tahap permainan

Langkah terakhir dari permainan tradisional Engklek yaitu gacuk diletakkan di telapak tangan dan punggung tangan. Artinya, pemain harus membolak-balikkan gacuk dari telapak tangan ke punggung tangan. Langkah ini merupakan langkah terakhir dari permainan tradisional Engklek yang mana pemain diharuskan untuk melakukan engkling pada setiap kotak sembari membawa gacuk yang dibolak-balik dari telapak tangan ke punggung tangan, kembali lagi ke telapak tangan dan seterusnya. Langkah kelima atau langkah terakhir dari permainan tradisional Engklek merupakan langkah yang paling sulit untuk dimainkan jika dibandingkan dengan langkah-langkah sebelumnya.

Permainan tradisional Engklek 
dapat dikatakan berakhir apabila para pemain berhasil melaksanakan semua langkah dalam permainan tradisional Engklek dari awal sampai akhir. Penelitian ini bukan hanya menonjolkan sisi karakter kerja keras dari permainan tradisional Engklek, namun keunikan lain seperti anakanak yang mampu belajar secara mandiri nilai karakter kerja keras dengan bermain permainan tradisional Engklek. Pemain dapat dikatakan sebagai pemenang apabila pemain tersebut mampu mendahului lawan mainnya dalam bermain dan mampu menjadi pemain pertama yang dapat menyelesaikan semua langkah permainan. Sedangkan pemain yang dikategorikan sebagai pemain yang kalah yaitu ketika pemain tersebut menjadi urutan terakhir dalam menyelesaikan langkah-langkah permainan tradisional Engklek.

Hasil pengamatan atau observasi yang dilakukan oleh peneliti terlihat bahwa pemain yang memenangkan permainan tradisional Engklek lantas tidak menjadi besar kepala dan tetap berhubungan baik dengan teman lainnya yang telah kalah dalam bermain. Sedangkan pemain yang telah kalah pun semakin terlihat nilai karakternya seperti karakter ikhlas.

\section{Implementasi Pendidikan Karakter} Kerja Keras pada Anak melalui
Permainan Tradisional Engklek di Dusun Pule, Tegalrandu, Srumbung, Magelang

Berdasarkan hasil wawancara, Sebelum anak-anak dapat mengimplementasikan karakter kerja keras dalam kehidupan sehari-hari, tentunya sang anak mengetahui terlebih dahulu karakter kerja keras yang mereka dapatkan dari orang tua. Tindakan yang dilakukan oleh para orang tua dalam memberikan pengetahuan tentang moral atau karakter kerja keras pada anak masuk pada salah satu unsur pokok dalam membangun pendidikan karakter menurut Thomas Lickona, yaitu knowing the good (mengetahui kebaikan). Thomas Lickona (Dalmeri, 2014:271) menjelaskan bahwa unsur pokok pendidikan karakter yang pertama kali harus dimiliki yaitu mengetahui kebaikan (knowing the good), yang mana pengetahuan tersebut didapatkan salah satunya dari narasumber. Orang tua menjadi narasumber pertama kali dalam kehidupan anak, sehingga para orang tua memberikan pengetahuan tentang moral kepada anak hingga akhirnya anak memahami karakter kerja keras dengan baik.

Karakter kerja keras memiliki beberapa ciri. Ciri-ciri tersebut berupa sikap-sikap atau perilaku-perilaku yang mengarah pada karakter kerja keras. Berdasakan hasil wawancara, ciri-ciri kerja keras yaitu tekun dan ulet, teliti dan 
cermat, menghargai waktu, bekerja keras, bekerja cerdas, disipilin, sabar, ikhlas dan pantang menyerah. Hal tersebut seperti yang dikatakan oleh Angelica Ardi (Handayani \& Sumaryati, 2014:31) bahwa ciri dari kerja keras adalah: tekun dan ulet, teliti dan cermat menghargai waktu dan bekerja keras, bekerja cerdas, disiplin, sabar, ikhlas, dan pantang menyerah.

Sebelum mengimplementasikan karakter kerja keras dalam kehidupan sehari-hari, anak-anak belajar secara mendiri kesembilan ciri kerja keras tersebut melalui permainan tradisional Engklek. Hal tersebut relevan dengan unsur desiring the good dari Thomas Lickona (Dalmeri, 2014:271) yang terlihat ketika anak-anak membiasakan diri untuk bermain permainan tradisional Engklek. Dari kebiasaan tersebut, anak yang awalnya mencintai permainan tradisional Engklek juga semakin mencintai nilai-nilai karakter kerja keras yang diajarkan dalam permainan tradisional Engklek. Adanya pembiasaan yang dilakukan oleh anakanak dalam belajar karakter kerja keras melalui permainan tradisional Engklek juga sesuai dengan pendapat dari Thomas Lickona (Dalmeri, 2014:271) bahwa pendidikan karakter tidak sekedar mengajarkan mana yang benar dan mana yang salah kepada anak, tetapi lebih dari itu pendidikan karakter menanamkan kebiasaan (habituation) tentang yang baik sehingga peserta didik paham, mampu merasakan, dan mau melakukan yang baik (Singh, 2019)

Setelah unsur knowing the good dan desiring the good dari Thomas Lickona berhasil diterapkan dalam penguatan pendidikan karakter kerja keras, selanjutnya anak-anak dapat mengimplementasikan karakter kerja keras yang sudah mereka miliki untuk dipraktikkan langsung dalam kehidupan sehari-hari. Disini, anak-anak sudah memasuki unsur yang ketiga yaitu doing the good atau melakukan kebaikan. Pendidikan karakter menurut Thomas Lickona (Dalmeri, 2014:271) mengandung tiga unsur pokok, yaitu mengetahui kebaikan (knowing the good), mencintai kebaikan (desiring the good), dan melakukan kebaikan (doing the good). Unsur doing the good dari Thomas Lickona relevan dengan implementasi-implementasi dari karakter kerja keras yang mampu mereka terapkan dalam kehidupan sehari-hari berikut ini :

a. Tekun dan Ulet

Berdasarkan hasil wawancara, karakter tekun dan ulet yang dapat diimplementasikan dalam kehidupan sehari-hari yaitu tekun dan ulet dalam belajar dan beribadah seperti sholat dan mengaji di TPA Dusun Pule. Indikator yang didapatkan dari karakter tekun dan ulet yaitu sungguhsungguh dan melakukan sesuatu secara terus menerus. 
b. Teliti dan Cermat

Karakter teliti dan cermat yang diimplementasikan dalam kehidupan sehari pada anak-anak yaitu teliti dan cermat dalam melakukan pekerjaan rumah, menyaring informasi yang didapatkan, dalam mengerjakan PR, serta teliti dan cermat dalam memilih kata-kata yang pantas ketika berbicara dengan orang lain. Indikator yang didapatkan dari nilai teliti dan cermat yaitu penuh kehati-hatian, tidak tergesa-gesa, serta penuh perhitungan dan pertimbangan dalam melakukan sesuatu.

c. Menghargai Waktu

Nilai menghargai waktu yang terlihat dalam kehidupan sehari-hari yang dilakukan oleh anak-anak yaitu seperti membuat perencanaan waktu yang matang, membuat jadwal kegiatan sehari-hari, dan memanfaatkan waktu luang untuk halhal yang bermanfaat seperti istirahat atau tidur siang. Indikator yang didapatkan dari karakter menghargai waktu yaitu menggunakan waktu yang ada untuk hal-hal yang bermanfaat dan sebaik mungkin.

Implementasi yang dilakukan oleh anak-anak dengan memanfaatkan waktu yang ada tersebut sesuai pendapat dari Kesuma (Pratiwi, 2016:10) bahwa karakteristik sikap kerja keras adalah perilaku seseorang yang dicirikan oleh berbagai kecenderungan salah satunya yaitu mampu mengelola waktu yang dimilikinya, sehingga nilai menghargai waktu juga merupakan karakteristik dari sikap kerja keras.

d. Bekerja Keras

Bekerja keras juga menjadi karakter yang dapat diimplementasikan oleh anak-anak yang terbiasa bermain permainan tradisional Engklek. Implementasi dari bekerja keras yang dilakukan oleh anak-anak yaitu membantu orang tua bekerja di sawah, mencari rumput untuk hewan ternak, lebih memilih untuk berjalan kaki ke sekolah, dan mengikuti gotong royong membersihkan dusun.

Dengan mengikuti gotong royong, sang anak secara tidak langsung juga turut melestarikan budaya gotong royong yang sudah ada sejak zaman dahulu, sehingga ia mampu berkontribusi dalam lingkungan masyarakat. Hal tersebut sesuai dengan pendapat dari Sriwilujeng (2017:4-5) bahwa PPK telah menjadi perhatian berbagai negara dalam rangka mempersiapkan generasi yang berkualitas, bukan hanya untuk kepentingan individu, tetapi juga untuk masyarakat secara keseluruhan.

Indikator yang didapatkan dari nilai bekerja keras setelah anak-anak mengimplementasikan nilai tersebut yaitu 
mampu menggunakan fisik dan tenaga yang dimiliki.

e. Bekerja Cerdas

Nilai dari bekerja cerdas juga dapat diimplementasikan dengan baik oleh anak-anak seperti mampu mencari peluang untuk nilai jual, contohnya yaitu menjual kue buatan ibunya untuk dijual di sekolah. Kemudian mampu memilih solusi yang terbaik untuk memudahkan pekerjaan tertentu seperti lebih memilih menangkap ikan di kolam rumahnya menggunakan jaring daripada menggunakan pancing. Yang terakhir yaitu mampu memanfaatkan barang yang sudah tidak berguna menjadi barang yang memiliki nilai guna seperti mengolah botol bekas menjadi tempat pensil. Indikator dari nilai bekerja cerdas yang muncul setelah mereka membiasakan diri bermain permainan tradisional Engklek yaitu mampu menggunakan pikiran atau akal disamping menggunakan fisik atau tenaga, mampu menyusun strategi, dan mampu berkonsentrasi.

f. Disiplin

Karakter disiplin dapat diimplementasikan dengan baik oleh anak-anak yaitu disiplin dalam mematuhi perintah orang tua, disiplin dalam melaksanakan jadwal piket TPA, disiplin dalam melaksanakan pembagian tugas keluarga dan disiplin waktu seperti tidak terlambat dan tepat waktu. Indikator dari karakter disiplin yang terlihat yaitu mematuhi aturan yang berlaku.

g. Sabar

Implementasi dari karakter sabar yang dapat dilakukan oleh anak-anak dalam kehidupan sehari-hari yaitu seperti sabar dalam menunggu buka puasa, sabar dalam mengasuh adik, dan sabar ketika berbicara dengan orang yang lebih tua. Implementasi yang ditunjukkan dengan bersikap sabar terhadap diri sendiri dan sabar terhadap orang lain tersebut sesuai dengan jurnal penelitian dari Irman (2017:95) yang menunjukkan bahwa permainan tradisional memperkuat karakter intrapersonal dan interpersonal, sehingga karakter yang dimiliki bukan hanya sebatas karakter pada diri sendiri, namun juga karakter yang ditunjukkan ketika berinteraksi dengan orang lain.

Kemudian indikator dari nilai sabar yaitu tidak mengeluh serta mampu menahan diri dari semua hal yang dapat memancing amarah, dan mampu menunggu sesuatu sampai tiba saatnya.

h. Ikhlas

Karakter ikhlas yang dapat diimplementasikan oleh anak-anak dalam kehidupan sehari-hari yaitu ikhlas jika diperintah oleh orang tua untuk pergi ke warung tanpa meminta imbalan, ikhlas berbagi makanan dan 
membantu orang lain, ikhlas beramal di masjid, dan ikhlas menerima uang pemberian orangtua berapa pun jumlahnya. Implementasi dari nilai keikhlasan yang dilakukan oleh anakanak dalam hal berbagi sesuai dengan hasil penelitian dari Roshayanti dkk (2014:329) bahwa salah satu pesan moral dari permainan tradisional Engklek yaitu mengajarkan untuk berbagi kepada sesama teman, sehingga pada dasarnya pesan moral tersebut sudah ada dalam permainan tradisional Engklek.

Kemudian indikator dari karakter ikhlas yang terlihat yaitu menerima dengan lapang dada, membantu tanpa pamrih, dan menanggapi suatu masalah sebagai suatu hal yang semestinya terjadi.

i. Pantang Menyerah

Karakter terakhir dari ciri kerja keras yaitu pantang menyerah. Implementasi dari karakter pantang menyerah yang dilakukan oleh anakanak dalam kehidupan sehari-hari yaitu melakukan pekerjaan sampai selesai seperti menyapu lantai sampai selesai dan bersih. Hal tersebut seperti yang dikatakan oleh Kesuma dkk (Nugroho, 2014:5) bahwa kerja keras dapat diartikan sebagai suatu usaha yang terus dilakukan (tidak pernah menyerah) dalam menyelesaikan pekerjaan atau yang menjadi tugasnya sampai tuntas tanpa henti.
Implementasi

lain

yang dilakukan oleh anak-anak yaitu pantang menyerah dalam menabung untuk mendapatkan sesuatu dan pantang menyerah untuk berpuasa. Sikap pantang menyerah dalam berpuasa juga sesuai dengan pendapat dari Thomas Lickona (Lickona, 2014:72) bahwa ketika kita berpikir tentang jenis karakter yang kita inginkan bagi anak kita, jelas bahwa kita ingin agar mereka mampu menilai hal yang baik dan buruk, sangat peduli pada hal yang benar, dan melakukan apa yang menurut mereka benar, bahkan disaat mereka dihadapkan pada tekanan dari luar dan godaan dari dalam. Seperti anak tersebut yang mampu menahan godaan dari dalam dirinya untuk membatalkan puasanya.

Kemudian indikator yang terlihat dari pantang menyerah yaitu berusaha terus menerus dan tidak menyerah dengan kondisi apapun.

\section{Simpulan}

Di Dusun Pule, tahapan permainan tradisional Engklek yang dipraktikkan oleh anak-anak yaitu tahap pra permainan dan tahap permainan. Tahap pra permainan memiliki lima langkah yaitu: (1) ngampiri teman-teman, (2) mencari tempat bermain, menggambar kotak permainan, (4) mencari gacuk, (5) melakukan 
hompimpa. Setelah pemain sudah mendapatkan urutannya masing-masing, masuk pada tahap yang kedua yaitu tahap permainan. Langkah-langkah dari tahap permainan yaitu: (1) lempar gacuk (engkling tanpa membawa gacuk), (2) Gacuk diletakkan di telapak tangan tanpa digenggam, (3) Gacuk diletakkan di punggung tangan, (4) Gacuk diletakkan di punggung tangan sembari digerakkan ke kanan dan kiri, (5) Gacuk dibolakbalikkan di telapak tangan dan punggung tangan.

Setelah anak-anak membiasakan diri dan sering bermain permainan tradisional Engklek, maka nilai-nilai karakter yang diajarkan dalam permainan tradisional Engklek dapat diimplementasikan dengan baik oleh mereka dalam kehidupan sehari-hari. Sembilan ciri kerja keras yang diajarkan dalam permainan tradisional Engklek ternyata dapat diimplementasikan dengan baik oleh anak-anak dalam kehidupan sehari-hari, yaitu: (1) Tekun dan ulet seperti dalam belajar dan beribadah (2) Teliti dan cermat seperti dalam melakukan pekerjaan rumah, menyaring informasi, berbicara dengan orang lain (3) Menghargai waktu seperti melakukan perencanaan waktu, membuat jadwal keseharian, dan memanfaatkan waktu luang (4) Bekerja keras seperti membantu orang tua dan gotong royong (5) Bekerja cerdas seperti memanfaatkan peluang sebagai nilai jual dan memanfaatkan sesuatu yang terbuang menjadi bermanfaat (6) Disiplin seperti mematuhi perintah orangtua dan disiplin waktu (7) Sabar seperti sabar menunggu buka puasa (8) Ikhlas seperti ikhlas beramal dan membantu tanpa pamrih (9) Pantang menyerah seperti melakukan pekerjaan sampai selesai.

\section{Ucapan Terima Kasih}

Terima kasih disampaikan kepada semua pihak yang terlibat dalam penelitian ini, sehingga terlaksana dengan baik dan tim redaksi Jurnal Pendidikan Sosiologi Fakultas IImu Sosial UNY yang telah mempublikasikan penelitian ini.

\section{Daftar Pustaka}

Alif, M. Z. (2013). Budaya Permainan sebagai Representasi dari Realita: Nilai dan Makna dalam Permainan Sondah Mandah di Indonesia. Jurnal ISBI Vol 1, No 2. Diakses pada 10 Maret 2019.

Ansori, M., Firdaus, A., Arinati, Zaenuddin, H., Hendrawan, B., Widyastuti, H., et al. (2016). Pendidikan Karakter Wirausaha. Batam: Penerbit Andi.

Apriani, D. (2013). Penerapan Permainan Tradisional Engklek untuk Meningkatkan Kemampuan Motorik Kasar Anak Kelompok B RA Al Hidayah 2 Tarik Sidoarjo. Jurnal Unesa Vol 2 No 1. Diakses pada 10 Maret 2019.

Cahyandari, A. G. (2014). Hompimpah : Sebuah Kajian Etnolinguistik pada Permainan Rakyat. Yogyakarta: Universitas Gadjah Mada.

Dalmeri. (2014). Pendidikan untuk Pengembangan Karakter (Telaah terhadap Gagasan Thomas 
Lickona dalam Educating for Character). Jurnal Al-Ulum Vol 14 No 1. Diakses pada 20 Maret 2019.

Handayani, N. W., \& Sumaryati. (2014). Upaya Orang Tua dalam Menanamkan Karaker Kerja Keras Anak Usia Remaja di Dusun Tegalyoso Banyuraden Gamping Sleman Yogyakarta. Jurnal Citizenship Vol 4 No 1. Diakses pada 16 Maret 2019.

Hanum, F. (2013). Sosiologi Pendidikan. Yogyakarta: Kanwa Publisher.

Kasnadi \& Sutejo. (2017). Permainan Tradisional sebagai Media Pendidikan Karakter. Prosiding Seminar Nasional PPKn III. STKIP PGRI Ponorogo.

Lickona, T. (2014). Pendidikan Karakter: Panduan Lengkap Mendidik Siswa Menjadi Pintar dan Baik. Bandung: Nusa Media.

Malik, H. (2011, April 7). Kompasiana. Retrieved Januari 20, 2019, from www.kompasiana.com.

Mardayani, K. T., \& dkk. (2016). Penerapan Permainan Tradisional Engklek untuk Meningkatkan Kemampuan Motorik Kasar Kelompok B di PAUD Widhya Laksmi. e-Journal Pendidikan Anak Usia Dini Vol 4 No 2. Diakses pada 16 Maret 2019.

Nugroho, W. S. (2014). Analisis Pengembangan Karakter Kerja Keras dalam Pembelajaran Pendidikan Kewarganegaraan pada Siswa Kelas VII SMP Negeri 2 Gatak Kabupaten Sukoharjo Tahun Pelajaran 2013/2014. Surakarta: Universitas Muhammadiyah Surakarta.

Pratiwi, A. A. (2016). Peningkatan Sikap Kerja Keras dan Prestasi Belajar IPS melalui Model Kooperatif Tipe Inside Outside Circle (IOC) pada Materi Masalah Sosial di Kelas IV SD Negeri 1 Besuki. Purwokerto: Universitas Muhammadiyah Purwokerto.

Roshayanti, F., \& dkk. (2014). Penerapan Pendidikan Karakter dalam
Pembelajaran Sains melalui Model Pembelajaran Berbasis Permainan Tradisional "Engklek". PROSIDING SEMNAS ENTREPRENEURSHIP (pp. Hal 326-340). Semarang: Universitas PGRI Semarang.

Singh, B. (2019). Character education in the 21st century. Journal of Social Studies (JSS), 15(1). 1-12. https://doi.org/10.21831/jss.v15i1.2 5226.

Sriwilujeng, D. (2017). Panduan Implementasi Penguatan Pendidikan Karakter. Jakarta: Erlangga.

Yudiwinata, H. P., \& Handoyo, P. (2014). Permainan Tradisional dalam Budaya dan Perkembangan Anak. Jurnal Paradigma Vol 2 No 3. Diakses pada 10 Maret 2019.

Yulita, R. (2017). Permainan Tradisional Anak Nusantara. Jakarta: Badan Pengembangan dan Pembinaan Bahasa, Kementerian Pendidikan dan Kebudayaan. 